\title{
Phosphorus, Zinc, and Boron Influence Yield Components in 'Earliglow' Strawberry
}

\author{
Geoffrey M. May and Marvin P. Pritts \\ Department of Fruit and Vegetable Science, Cornell University Ithaca, NY 14853
}

Additional index words. Fragaria $\times$ ananassa, interaction, nutrition

\begin{abstract}
The main effects and interactions of soil-applied $\mathbf{P}, \mathbf{B}$, and $\mathrm{Zn}$ on yield and its components were examined in the field at two pH levels with 'Earliglow' strawberries (Fragaria $\times$ ananassa Duch.). Applied nutrients had significant effects on several yield components, but responses depended on the levels of other nutrients or the soil pH At a soil $\mathrm{pH}$ of 5.5, yield responded linearly to $\mathrm{B}$ and quadratically to $\mathrm{P}$. At $\mathrm{pH} 6.5$, $\mathrm{P}$ interacted with $\mathrm{B}$ and $\mathrm{Zn}$. Fruit count per inflorescence was the yield component most strongly associated with yield followed by individual fruit weight. However, these two yield components responded differently to soil-applied nutrients. Foliar nutrient levels generally did not increase with the amount of applied nutrient, but often an applied nutrient had a strong effect on the level of another nutrient. Leaf nutrient levels were often correlated with fruit levels, but foliar and fruit levels at harvest were not related to reproductive performance. Our study identifies some of the problems inherent in using foliar nutrient levels to predict a yield response and demonstrates how plant responses to single nutrients depend on soil chemistry and the presence of other nutrients.
\end{abstract}

Achieving the optimum level of nutrition for horticultural crops is a major objective of practitioners. Realization of this objective is complicated because: 1) at least 12 essential nutrients are involved, 2) many environmental factors influence the availability and uptake of these nutrients, 3) genetic differences in uptake and usage exist at all taxonomic levels, and 4) nutrients interact among themselves.

The first three items have been explored extensively for most major crops, including strawberries (May and Pritts, 1990). However, investigations of nutrient interactions in the field have been lacking because of the difficulty in testing for such effects. For example, scientists often use factorial experiments to test for interactions. An experiment designed to quantify interactions among three factors at five levels would result in 125 treatment combinations if a complete factorial design was used. When replication is introduced, the number of experimental units becomes unmanageable.

Response surface methodology has been developed to enable the researcher to minimize the number of treatment combinations for the generation of a multidimensional response (Box and Draper, 1987). Using the above example, only 15 treatment combinations are needed to generate a response surface, assuming no third order or higher responses or interactions exist (Cochran and Cox, 1957). The ability to use fewer treatment combinations to generate response surfaces allows the study of nutrient interactions in field situations.

Strawberries are an ideal model for nutrient interaction studies in perennial crops. First, they are relatively precocious, producing their first crop within months of planting. Second the plants are small, so that many plots can be established within uniform soils. Third, they can be easily excavated and divided into vegetative and reproductive components, allowing for detailed evaluation of observed growth or yield responses. Fourth,

Received for publication 8 Jan. 1992. Accepted for publication 17 June 1992 Fruit and Vegetable Science Paper no. 27. This work was supported by Hatch Project NYS142-402 and a grant from the North American Strawberry Growers Assn. We thank Kathy Worden and Judy Kozlowski for their help with data collection, Leon Kochian, Warren Stiles, and Mary Jo Kelly for their review and Mike Rutzke for assistance with nutrient analysis. The cost of publishing this paper was defrayed in part by the payment of page charges. Under postal regulations, this paper therefore must be hereby marked advertisement solely to indicate this fact. when compared to other perennial fruit crops, cropping history has little influence on flower bud initiation and fruiting.

The objective of our research was to evaluate the main effects and interations among $\mathrm{P}, \mathrm{Zn}$, and B as they affect tissue nutrient status and yield in 'Earliglow' strawberry. These three nutrients were chosen for several reasons. First, a negative P-Zn interaction has been reported in other crops (Barnette et al., 1936; Murphy et al., 1981; Olsen, 1972; West, 1938). Second a survey of leaf analysis results found that $\mathrm{Zn}$ and B were consistently low in strawberry plantings, and $\mathrm{P}$ was often excessive (Mitlehner, 1989). Our review of results from Cornell Univ.'s Plant Tissue Analysis Laboratory, Ithaca, N.Y., reflected a similar pattern. Third, those who grow strawberries in matted-rows often use a P-containing fertilizer at renovation, even though $\mathrm{P}$ levels are usually amended at planting. If $\mathrm{P}$ does interact negatively with these other nutrients, then fertilization practices at renovation may require modification.

A second objective was to determine if main effects and interactions were consistent at different soil $\mathrm{pH}$ levels. Soil $\mathrm{pH}$ is known to have a major effect on nutrient availabilty, and since commercial fields vary considerably in $\mathrm{pH}$, it is important to know how widely applicable results are from experiments conducted under a single set of conditions.

We selected a soil for the experiment that was not deficient in $\mathrm{P}, \mathrm{B}$, or $\mathrm{Zn}$, a situation typical of most soils on which strawberries are grown in the northeastern United States. However we used a wide range of nutrient additions to generate imbalances that might occur in a commercial situation, recognizing that responses would likely be different (and possibly stronger) on nutrient-poor soils.

\section{Materials and Methods}

Interactions among $\mathrm{P}, \mathrm{B}$, and $\mathrm{Zn}$ at two $\mathrm{pH}$ levels in 'Earliglow' strawberry were examined at Cornell Orchards, Ithaca N.Y. The soil was a Collamer silt loam (Typic Hapludalf, $\mathrm{pH}$ $=5.5$ ). Soil testing before treatment application, using an ammonium acetate extraction procedure, indicated about (kg-ha-') $11 \mathrm{P}, 92 \mathrm{~K}, 2800 \mathrm{Ca}, 435 \mathrm{Mg}, 159 \mathrm{Fe}, 139 \mathrm{Mn}, 2.2 \mathrm{Zn}, 0.2$ $\mathrm{B}$, and $6.7 \mathrm{Cu}$.

A three-factor, rotatable, central composite design (Cochran and Cox, 1957) was used to identify the specific orthogonal treatment combinations required to obtain a second-order re- 
sponse surface. Fifteen treatment combinations from five levels each of $\mathrm{P}, \mathrm{Zn}$, and B (Table 1) were selected according to design criteria. Treatments were applied in a randomized completeblock design and replicated three times, at two $\mathrm{pH}$ levels (5.5 and 6.5), for a total of 90 experimental units with dimensions of $2.5 \times 3.5 \mathrm{~m}$ each.

Nutrients were soil-incorporated before planting. Rates of application ranged from 11 to $123 \mathrm{~kg} \mathrm{P} / \mathrm{ha}$ as triple super phosphate, 2.8 to $45 \mathrm{~kg} \mathrm{Zn} / \mathrm{ha}$ as zinc sulfate, and 0.2 to $4.5 \mathrm{~kg} \mathrm{~B} /$ ha as sodium octaborate. Ground agricultural limestone was used to adjust soil $\mathrm{pH}$ level in half of the plots from the existing $\mathrm{pH}$ of 5.5 to 6.5 .

Applications of P, Zn, B, and lime were made in Oct. 1986 before rototilling of each plot. To ensure uniform distribution, zinc sulfate and sodium octaborate were first dissolved in water, then applied to each plot using a hand sprayer. Other than $\mathrm{N}$, no additional nutrients were applied during the course of the experiment. Subsequent soil testing (ammonium acetate extraction) was conducted in Spring and Fall 1987 and in Spring 1988.

On 23 Apr. 1987, certified nursery plants of 'Earliglow' were planted $30 \mathrm{~cm}$ on square, forming a 40-plant grid in each plot. Standard cultural practices were followed (Pritts et al., 1988), with the exception that runners were removed so plants did not form a solid bed. Napropamide at $2.2 \mathrm{~kg} \cdot \mathrm{ha}^{-1}$ was applied 2 weeks after planting and again at $4.5 \mathrm{~kg} \cdot \mathrm{ha}^{-1}$ before straw mulch application in November. Ammonium nitrate was applied 6 weeks after planting to supply $34 \mathrm{~kg} \mathrm{~N} / \mathrm{ha}$, and calcium nitrate was applied in early September to supply $22 \mathrm{~kg} \mathrm{~N} / \mathrm{ha}$. Soil moisture was maintained near field capacity throughout the study with overhead irrigation, as indicated by soil moisture tensiometers.

Runners were removed weekly to maintain a constant plant density within each plot. Entire plants were excavated beginning 2 June 1987 and continuing at $\approx 30$-day intervals throughout the first year of establishment (1987) and first fruiting season (1988). Plants were separated into roots, crowns, petioles, leaf blades, and fruit, washed with tap water, then rinsed with distilled water. Plant material was oven-dried at $65 \mathrm{C}$, weighed, and ground in a Wiley mill to pass through square grids $1.4 \times 1.7 \mathrm{~mm}$.

Nitrogen concentration in leaf lamina was determined by a Kjeldahl procedure. The $\mathrm{P}, \mathrm{K}, \mathrm{Ca}, \mathrm{Mg}, \mathrm{Fe}, \mathrm{Zn}, \mathrm{B}, \mathrm{Mn}, \mathrm{Cu}$,

Table 1. Treatment combinations specified by the three-factor, rotatable, central composite design and corresponding yields in 1988 at $\mathrm{pH} 5.5$ and 6.5 .

\begin{tabular}{|c|c|c|c|c|c|}
\hline \multirow{2}{*}{$\begin{array}{c}\text { Treatment } \\
\text { number }\end{array}$} & \multirow{2}{*}{$\frac{\mathrm{P}}{\mathrm{kg} \cdot \mathrm{ha} \mathrm{a}^{-1}}$} & \multirow{2}{*}{$\frac{\mathrm{Zn}}{\mathrm{kg} \cdot \mathrm{ha}^{-1}}$} & \multirow{2}{*}{$\frac{\mathrm{B}}{\mathrm{kg} \cdot \mathrm{ha} \mathrm{a}^{-1}}$} & \multicolumn{2}{|c|}{ Yield (g) } \\
\hline & & & & $\mathrm{pH}=5.5$ & $\mathrm{pH}=6.5$ \\
\hline 1 & 11.2 & 23.9 & 2.4 & $1544^{z}$ & 1507 \\
\hline 2 & 33.6 & 11.4 & 1.1 & 1369 & 1544 \\
\hline 3 & 33.6 & 11.4 & 3.6 & 1460 & 1688 \\
\hline 4 & 33.6 & 36.3 & 1.1 & 1450 & 1172 \\
\hline 5 & 33.6 & 36.3 & 3.6 & 2019 & 1513 \\
\hline 6 & 67.3 & 2.9 & 2.4 & 1293 & 1629 \\
\hline 7 & 67.3 & 23.9 & 0.2 & 1474 & 1386 \\
\hline 8 & 67.3 & 23.9 & 2.4 & 1233 & 1372 \\
\hline 9 & 67.3 & 23.9 & 4.5 & 1428 & 1566 \\
\hline 10 & 67.3 & 44.8 & 2.4 & 1506 & 1099 \\
\hline 11 & 100.9 & 11.4 & 1.1 & 1456 & 1453 \\
\hline 12 & 100.9 & 11.4 & 3.6 & 1655 & 1957 \\
\hline 13 & 100.9 & 36.3 & 1.1 & 1494 & 1243 \\
\hline 14 & 100.9 & 36.3 & 3.6 & 1645 & 1482 \\
\hline 15 & 123.3 & 23.9 & 2.4 & 1766 & 1440 \\
\hline SE & & & & 43 & 43 \\
\hline
\end{tabular}

${ }^{2}$ Means are the average of three six-plant replicates. and Mo content was determined by inductively coupled plasma spectroscopy (Model 975 Plasma Atomcomp ICP Spectrograph with ICAP 61 Update, Jarrell-Ash, Pittsburgh). Leaf area was determined using a portable area meter (LI-COR Model LI3100, Lincoln, Neb. Aboveground plant dry weight, number of branch crowns and fruit per inflorescence, inflorescence length, fruit count per plant, fruit weight, achenes per square centimeter of surface, and fruit weight per achene were recorded at each sampling date. Yield component data were pooled for each plot. A final leaf sample for tissue nutrient analysis was collected $\approx 5$ weeks after postharvest leaf removal. Fruit soluble solids concentration (SSC) was determined with a hand-held refractometer (Thomas Scientific, Swedesboro, N.J.).

Statistical analysis of the central composite design was used to derive meaningful regression equations that accurately described the response surfaces for the variables of interest. Values for nutrient concentrations were transformed before analysis by first subtracting the mean, then dividing by it, resulting in a scale from -1 to 1 for each nutrient. Using a transformed scale in regression analysis has three advantages over using the actual levels of applied nutrient. First, regardless of the nutrient involved, -1 represents a low level and +1 a high level. This scheme is important when the differences in ranges between low and high levels are very large (as was the case with $\mathrm{P}$ and B). Second, the transformed variables are orthogonal, allowing unbiased estimates of regression coefficients to be calculated. Third, regression coefficients among components of the model can be compared directly with each other. Also, this standardized scale can be converted easily to the actual applied values through multiplication.

These new, orthogonal variables were used in regression analysis to calculate the response surface, using the following full model: Response $=$ Block $+\mathrm{P}+\mathrm{Zn}+\mathrm{B}+\mathrm{P} \times \mathrm{Zn}$ $+\mathrm{P} \times \mathrm{B}+\mathrm{B} \times \mathrm{Zn}+\mathrm{P}^{2}+\mathrm{B}^{2}+\mathrm{Zn}^{2}$.

Sequential sums of squares were accumulated for the full model. Single-degree-of-freedom F tests were then used to evaluate the significance of the individual components of the model. For the generation of response surfaces, new models were constructed using only the significant terms from the full model, with the exception of fruit count per inflorescence, where the full model was used (since the full model was significant, but individual coefficients were not).

\section{Results}

Preplant, soil-applied nutrient additions of $\mathrm{P}, \mathrm{Zn}$, and B were correlated with soil test results in each of the 2 years (Table 2). A decrease of $\approx 0.5 \mathrm{pH}$ units was measured during the course of the experiment in plots that initially received lime applications. Plant growth variables were unaffected by liming; however, yield components were affected differently at $\mathrm{pH} 5.5$ and 6.5 , so results are discussed separately.

Results at $p H$ 6.5. Yield increased with increasing B at a high $\mathrm{P}$ level but decreased at a low $\mathrm{P}$ level (Table 1, Fig. 1 top).

Table 2. Significant $(P<0.01)$ correlation coefficients $(r)$ between mineral nutrient treatment levels (1986) and soil test values (1987 and 1988).

\begin{tabular}{lccc}
\hline \hline Soil test & P & Zn & B \\
\hline Spring 1987 & 0.94 & 0.97 & 0.84 \\
Fall 1987 & 0.74 & 0.65 & NS \\
Spring 1988 & 0.55 & 0.93 & 0.71 \\
\hline
\end{tabular}

NSNonsignificant. 

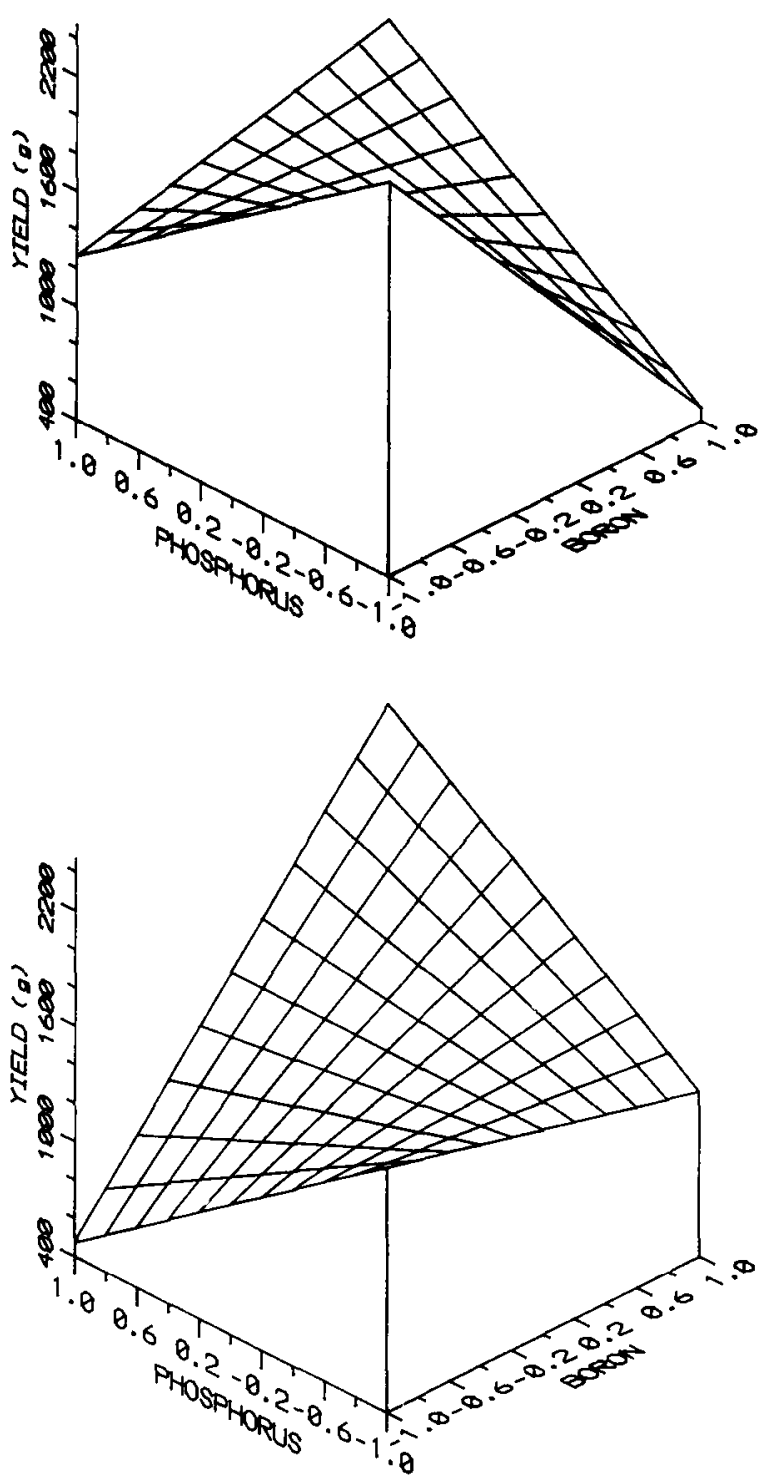

Fig. 1. Yield response (grams per six plants) to $\mathrm{P}$ and $\mathrm{B}$ at $\mathrm{pH}=$ 6.5. For scale conversion, units of $\mathrm{P}$ range from $11.2(-1)$ to 123.3 (1) $\mathrm{kg} \cdot \mathrm{ha}^{-1}$ and $\mathrm{B}$ from $0.2(-1)$ to 4.5 (1) $\mathrm{kg} \cdot \mathrm{ha}^{-1}$. (Top) $\mathrm{Zn}=$ $1.0\left(45 \mathrm{~kg} \cdot \mathrm{ha}^{-1}\right)$. Yield $=1470+605\left(\mathrm{P}^{*} \mathrm{~B}\right)-394(\mathrm{~B} * \mathrm{Zn}), R^{2}=$ 0.213, $P<0.007$. (Bottom) $\mathrm{Zn}=-1.0\left(2.9 \mathrm{~kg} \cdot \mathrm{ha}^{-1}\right)$. Yield $=$ $1470+605(\mathrm{P} * \mathrm{~B})+394(\mathrm{~B} * \mathrm{Zn}), R^{2}=0.213, P<0.007$.

Zinc moderated this response (Fig 1 bottom), reflecting an interaction of $\mathrm{P}$ with $\mathrm{B}$ and $\mathrm{Zn}$ (Table 3 ). Fruit count per inflorescence was the only yield component correlated strongly with yield $r=0.62, P<0.01$ ), although fruit size and yield were marginally correlated $(r=0.29, P<0.06)$. The response surface for fruit count per inflorescence resembled that of yield, but the regression coefficients were not statistically significant (Fig. 2). Branch crown count was significantly affected by $P$ and $\mathrm{B}$ but exhibited a very different response surface than that for yield (Fig. 3). Nutrient treatments had no effect on fruit SSC, fruit size, achene spacing, or inflorescence count, although inflorescence length was associated positively with a wider achene spacing on the fruit receptacle $(r=0.34, P<$ 0.02).

Foliar levels of $\mathrm{P}, \mathrm{Zn}$, and B fluctuated during the season (Fig. 4), and by renovation in 1988, only $\mathrm{P}$ was still influenced significantly by the soil nutrient addition made in $1986(\mathrm{r}=$
Table 3. Yield components and reproductive variables with significant regression coefficients for the full response surface model.

\begin{tabular}{ll}
\hline \hline & Variable \\
\hline Dependent & Independent \\
\hline & $p H 6.5$ \\
Yield & $606(\mathrm{P} \times \mathrm{B})^{* * *},-395(\mathrm{P} \times \mathrm{Zn})^{*}$ \\
Branch crowns/plant & $-2.35\left(\mathrm{P}^{2}\right)^{*}$ \\
Inflorescences/plant & None \\
Fruit/inflorescence & None \\
Individual fruit wt & None \\
Achenes/fruit & None \\
Achene density & None \\
Soluble solids & None \\
concn & None \\
Runners/plant & $12.2\left(\mathrm{~B}^{2}\right)^{*},-1.35(\mathrm{Zn})^{*}$ \\
Aboveground plant wt & $p H 5.5$ \\
& $167(\mathrm{~B})^{*}, 658\left(\mathrm{P}^{2}\right)^{* *}$ \\
Yield & $4.36(\mathrm{P} \times \mathrm{B})^{* * *}, 6.09(\mathrm{P} \times \mathrm{Zn})^{* * *}$ \\
Branch crowns/plant & None \\
Inflorescences/plant & None \\
Fruit/inflorescence & $0.368(\mathrm{P})^{*}, 0.349(\mathrm{~B})^{*}$ \\
Individual fruit wt & None \\
Achenes/fruit & None \\
Achene density & None \\
Soluble solids & $-31.4(\mathrm{Zn})^{* *}, 30.1(\mathrm{Zn})^{* *}$ \\
concn & $210(\mathrm{P})^{* *}, 200(\mathrm{P} \times \mathrm{Zn})^{* *}$ \\
Runners/plant & \\
Above-ground plant wt & \\
\hline$* * * * 10.05,0.01$
\end{tabular}

$*, * *, * * *$ Probability of significance is $P<0.10,0.05$, or 0.01 , respectively.

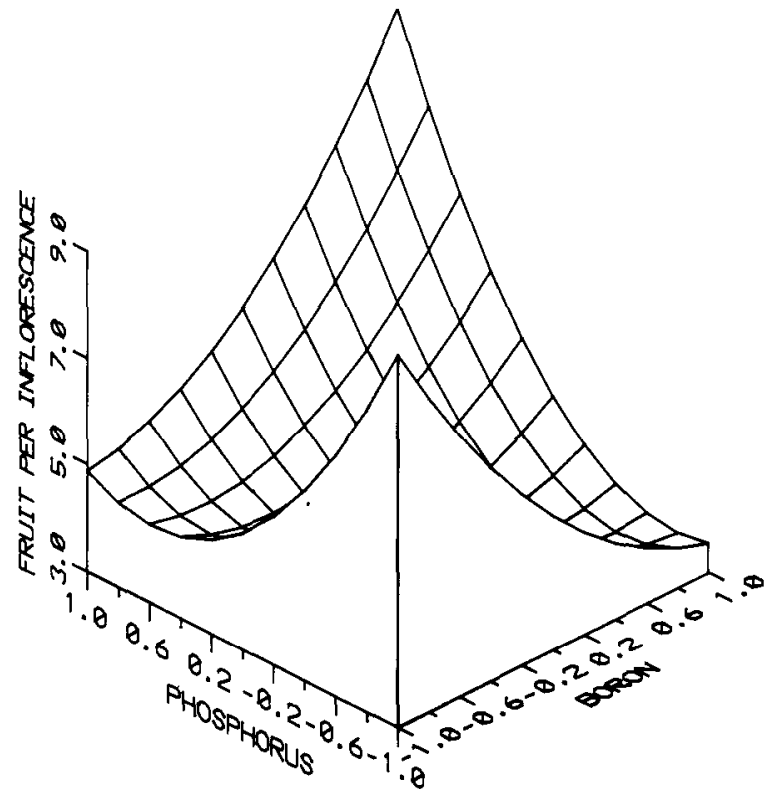

Fig. 2. Response of fruit per inflorescence to $\mathrm{P}$ and $\mathrm{B}$ at $\mathrm{Zn}=0$ $\left(23.9 \mathrm{~kg} \cdot \mathrm{ha}^{-1}\right)$ and $\mathrm{pH}=6.5$. Fruit count $=3.74+0.488(\mathrm{P})+$ $2.25\left(\mathrm{P}^{2}\right)-0.177(\mathrm{~B})+1.26\left(\mathrm{~B}^{2}\right)+3.04(\mathrm{P} * \mathrm{~B}), R^{2}=0.133$, nonsignificant. For scale conversion, units of $\mathrm{P}$ range from $11.2(-1)$ to 123.3 (1) $\mathrm{kg} \cdot \mathrm{ha}^{-1}$ and B from $0.2(-1)$ to 4.5 (1) $\mathrm{kg} \cdot \mathrm{ha}^{-1}$.

$0.29, P<0.05)$. Leaf $\mathrm{P}$ generally increased with soil $\mathrm{P}>30$ $\mathrm{kg} \cdot \mathrm{ha}^{-1}$, but decreased as soil B increased (Fig. 5). Leaf B and $\mathrm{Zn}$, however, were positively influenced by the level of applied $\mathrm{P}(P<0.02)$ but not by the level of applied B or $\mathrm{Zn}$.

None of the foliar nutrient levels at renovation were correlated 


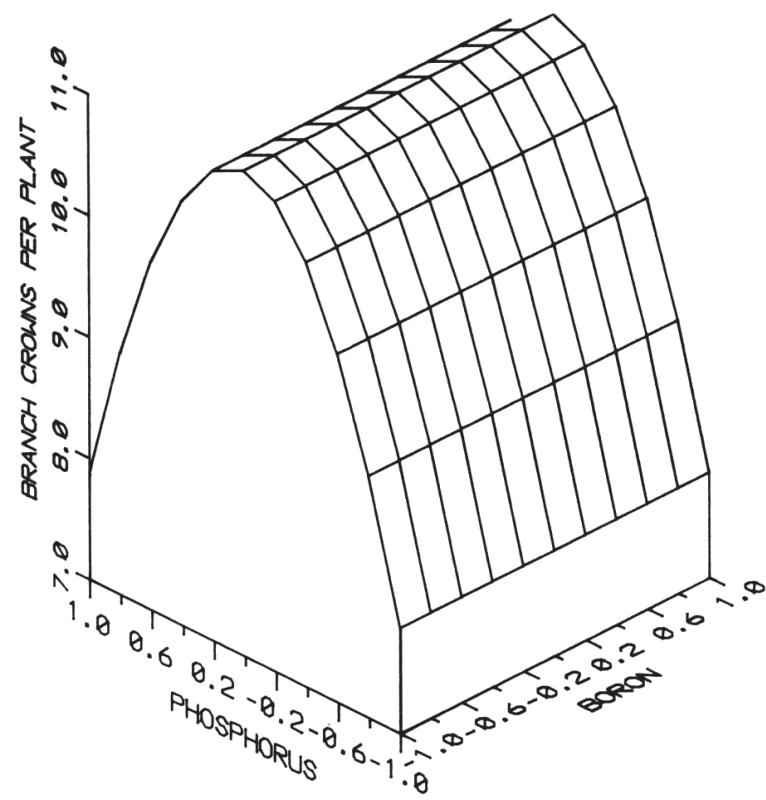

Fig. 3. Response of branch crowns per plant to $\mathrm{P}$ and $\mathrm{B}$ at $\mathrm{Zn}=0$ $\left(23.9 \mathrm{~kg} \cdot \mathrm{ha}^{-1}\right)$ and $\mathrm{pH}=6.5$. Branch crown count $=11.0-$ $3.13\left(\mathrm{P}^{2}\right), R^{2}=0.09, P<0.05$. For scale conversion, units of $\mathrm{P}$ range from $11.2(-1)$ to $123.3(1) \mathrm{kg} \cdot \mathrm{ha}^{-1}$ and $\mathrm{B}$ from $0.2(-1)$ to $4.5(1) \mathrm{kg} \cdot \mathrm{ha}^{-1}$.

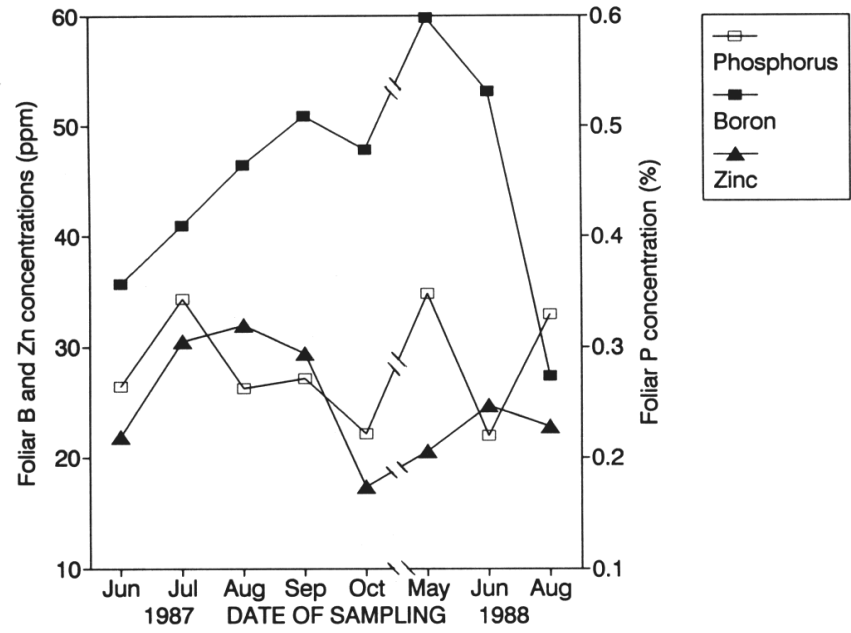

Fig. 4. Seasonal pattern of $\mathrm{P}, \mathrm{B}$, and $\mathrm{Zn}$ concentration in leaf lamina of plants set in Apr. 1987 and harvested over the following 16 months for the central treatment of the design of the experiment $\left(\mathrm{kg} \cdot \mathrm{ha}^{-1}\right.$ : $67 \mathrm{P}, 23.9 \mathrm{Zn}$, and $\left.2.35 \mathrm{~B}\right)$.

with yield. For $\mathrm{K}, \mathrm{P}, \mathrm{Ca}, \mathrm{Mn}, \mathrm{Cu}$, and $\mathrm{Zn}$, foliar and fruit levels were correlated positively, but no correlation existed for levels of $\mathrm{Mg}, \mathrm{Fe}$, or B. Plant size was not correlated with yield.

Results at $p H$ 5.5. Strawberry yields were significantly affected by B (Fig. 6), but the interaction of $\mathrm{B}$ with $\mathrm{P}$ or $\mathrm{Zn}$ was not significant (Table 3). Boron applications increased yield regardless of $\mathrm{P}$ and $\mathrm{Zn}$ levels. As at the higher $\mathrm{pH}$, fruit count per inflorescence $(r=0.65, P<0.001)$ and individual fruit weight $(r=0.31, P<0.04)$ were correlated with yield, and their responses to nutrient additions somewhat paralleled the yield response (Figs. 7 and 8). Again, although the response of fruit count per inflorescence was very similar to that of yield, regression coefficients that describe the response of this variable to nutrient additions were not significant (Fig. 8).

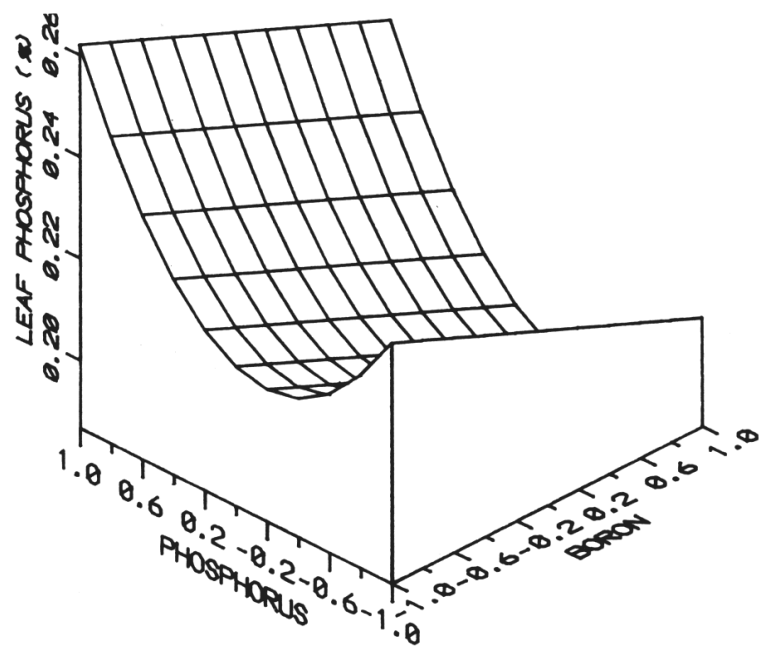

Fig. 5. Response of leaf $\mathrm{P}$ at renovation to $\mathrm{P}$ and $\mathrm{B}$ at $\mathrm{Zn}=0(23.9$ $\mathrm{kg} \cdot \mathrm{ha}^{-1}$ ) and $\mathrm{pH}=6.5$. Percent leaf $\mathrm{P}=0.201+0.014(\mathrm{P})+$ $0.034\left(\mathrm{P}^{2}\right)-0.013(\mathrm{~B})-0.03\left(\mathrm{~B}^{*} \mathrm{Zn}\right), R^{2}=0.339, P<0.002$. For scale conversion, units of $\mathrm{P}$ range from $11.2(-1)$ to $123.3(1)$ $\mathrm{kg} \cdot \mathrm{ha}^{-1}$ and B from $0.2(-1)$ to $4.5(1) \mathrm{kg} \cdot \mathrm{ha}^{-1}$.

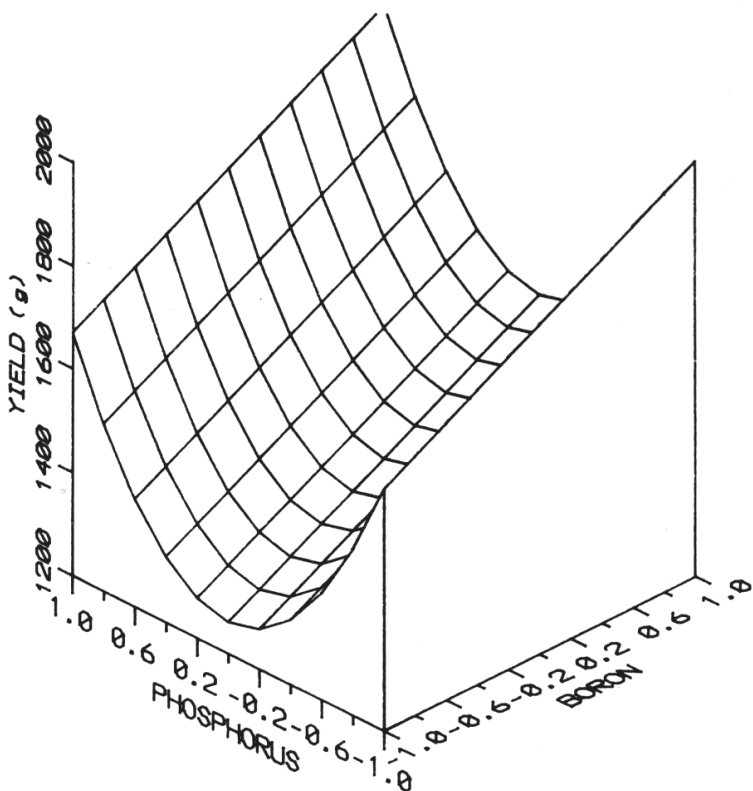

Fig. 6. Yield response (grams per six plants) to $\mathrm{P}$ and $\mathrm{B}$ at $\mathrm{Zn}=0$ $\left(23.9 \mathrm{~kg} \cdot \mathrm{ha}^{-1}\right)$ and $\mathrm{pH}=5.5$. Yield $=1427+410\left(\mathrm{P}^{2}\right)+166(\mathrm{~B})$, $R^{2}=0.153, P<0.03$. For scale conversion, units of $\mathrm{P}$ range from $11.2(-1)$ to $123.3(1) \mathrm{kg} \cdot \mathrm{ha}^{-1}$ and B from $0.2(-1)$ to $4.5(1)$ $\mathrm{kg} \cdot \mathrm{ha}^{-1}$.

Nutrient additions had no effect on inflorescence count, fruit SSC, or achene spacing (Table 3). Inflorescence length, however, was positively correlated with fruit size $(r=0.39, P<$ $0.009)$, yield $(r=0.36, P<0.02)$, achene spacing $(r=0.34$, $P<0.02)$, and the level of applied B $(r=0.31, P<0.04)$.

Leaf $\mathrm{P}$ at renovation showed a quadratic response to soilapplied $\mathrm{P}$ (data not shown), similar to that at the higher $\mathrm{pH}$ (Fig. 5). Leaf $\mathrm{B}$ exhibited a quadratic response to $\mathrm{P}(P<0.06)$ but not to B additions (data not shown).

Leaf $\mathrm{Zn}$ at renovation was negatively correlated with yield $(P<0.06)$, but correlations of yield with other foliar nutrient levels at renovation were not significant (data not shown). Fruit and leaf nutrient levels were correlated positively for $\mathrm{P}, \mathrm{Mn}$, 


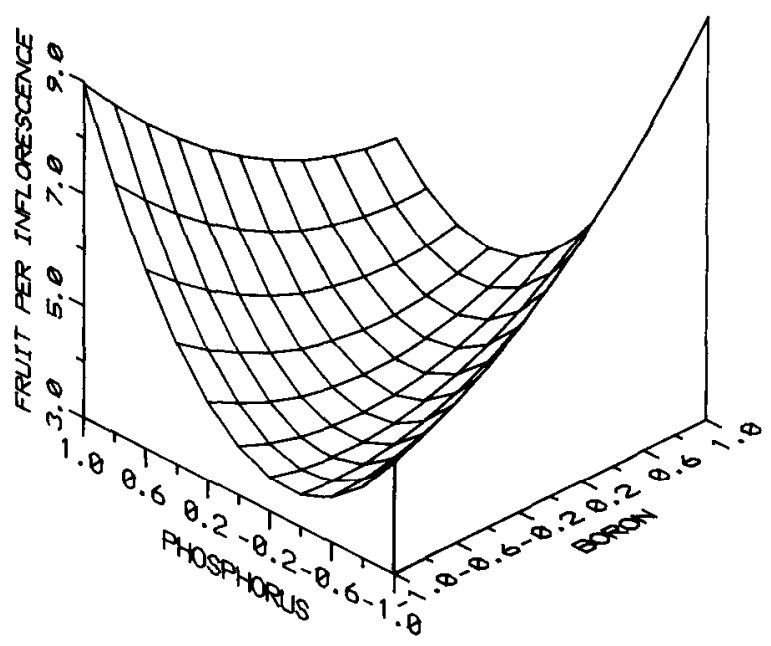

Fig. 7. Response of fruits per inflorescence to $\mathrm{P}$ and $\mathrm{B}$ at $\mathrm{Zn}=0$ $\left(23.9 \mathrm{~kg} \cdot \mathrm{ha}^{-1}\right)$ and $\mathrm{pH}=5.5$. Fruits number $=3.42-0.249(\mathrm{P})$ $+3.11\left(\mathrm{P}^{2}\right)+0.364(\mathrm{~B})+0.814\left(\mathrm{~B}^{2}\right)-2.23(\mathrm{P} * \mathrm{~B}), R^{2}=0.306$, nonsignificant. For scale conversion, units of $\mathrm{P}$ range from 11.2 (- 1) to 123.3 (1) $\mathrm{kg} \cdot \mathrm{ha}^{-1}$ and B from 0.2 (- 1) to 4.5 (1) $\mathrm{kg} \cdot \mathrm{ha}^{-1}$.

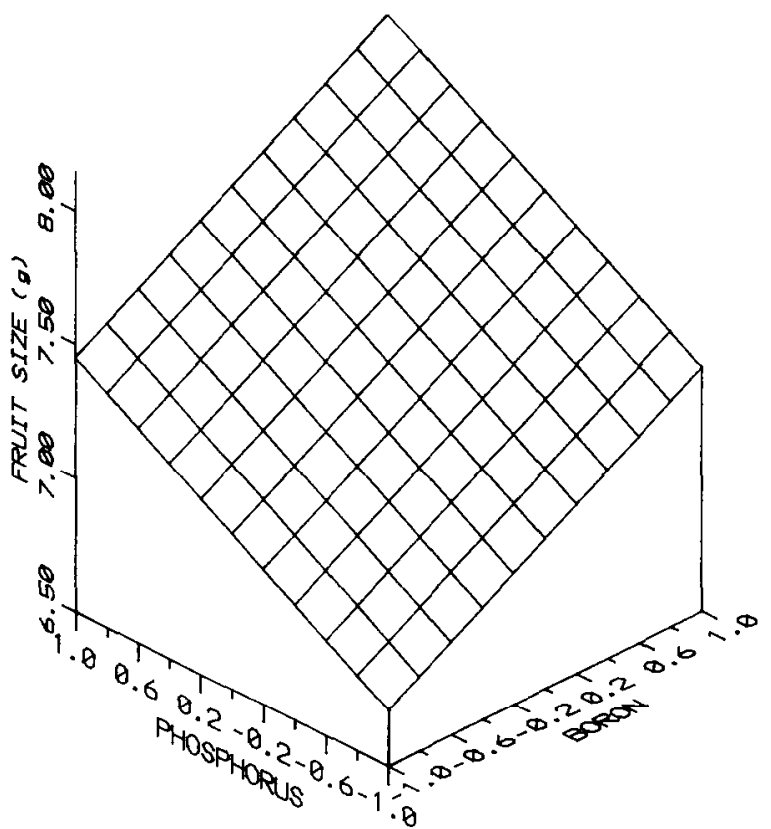

Fig. 8. Response of mean individual fruit weight (grams per berry) to $\mathrm{P}$ and $\mathrm{B}$ at $\mathrm{Zn}=0\left(23.9 \mathrm{~kg} \cdot \mathrm{ha}^{-1}\right)$ and $\mathrm{pH}=5.5$. Individual fruit weight $=7.43+0.368(\mathrm{P})+0.349(\mathrm{~B}), R^{2}=0.423, P<$ 0.04 . For scale conversion, units of $\mathrm{P}$ range from $11.2(-1)$ to 123.3 (1) $\mathrm{kg} \cdot \mathrm{ha}^{-1}$ and B from 0.2 (- 1) to 4.5 (1) $\mathrm{kg} \cdot \mathrm{ha}^{-1}$.

$\mathrm{Fe}, \mathrm{Cu}, \mathrm{B}$, and $\mathrm{Zn}$, but not for $\mathrm{Ca}$ or $\mathrm{Mg}$. Plant size was not correlated with yield.

\section{Discussion}

The response of crop plants to applied nutrients in commercial situations can be obtained only through field studies. However, field studies involving applied nutrients have many inherent difficulties, such as the lack of uniformity in soils and the presence of secondary nutrients that are contained in most fertilizer sources. For example, in our experiment, we attempted to establish two levels of soil $\mathrm{pH}$ with a limestone amendment. The responses that we observed could have been influenced by the $\mathrm{Ca}$ and $\mathrm{Mg}$ in the lime, rather than just the $\mathrm{pH}$. Further, we assumed that responses to applied triple superphosphate were related to $\mathrm{P}$, although this nutrient source also contains $\mathrm{Ca}, \mathrm{S}, \mathrm{Fe}$, and $\mathrm{Al}$ (Ozanne, 1980). The $\mathrm{Zn}$ source that we used also contains S, and the B source contains Na. While recognizing that the potential for confounding influences exists, for the purpose of this discussion, we attribute responses to the applied nutrient of interest.

Another major difficulty encountered with field studies is that it is not always known which nutrients are limiting plant growth or yield. Preferably one would begin with a situation where all nutrients are unlimited, except for those nutrients of interest, which are absent. In sand and solution cultures, these conditions can be realized. However, in field soils, baseline levels of essential nutrients almost always exist, and one cannot know with certainty the status of the planting along the nutrient response curve without extensive experimental investigation.

Given the number of limitations to field studies, we will not attempt to provide mechanistic explanations for the responses that we observed. Rather, we will make three major points that do not depend on knowing the exact nutrient status of the soil or the response of plants to individually applied nutrients from deficient through toxic levels. These points are as follows: 1) soil $\mathrm{pH}$ can alter plant response to applied nutrients; 2) predictions about plant response to applied nutrients are difficult when interactions with other nutrients exist; and 3) individual yield components respond differently to applied nutrients, implying that there may be more than one optimal combination of nutrients for maximum yield.

Nutrient interactions and soil $\mathrm{pH}$ influenced plant response to individual nutrients. Yield and certain yield components exhibited a strong response to soil-applied B (Figs. 1, 6, and 8). However, the yield response of strawberries to soil-applied B depended on the level of soil $\mathrm{P}$ and $\mathrm{pH}$. Yields at the higher $\mathrm{pH}$ (6.5) varied among treatments nearly 2 -fold, due primarily to interactions of $\mathrm{P}$ with $\mathrm{B}$ and $\mathrm{Zn}$. Yield at the lower $\mathrm{pH}$ was also influenced by $\mathrm{P}$ and $\mathrm{B}$ but not by an interaction between the two nutrients (Fig. 6).

The existence of nutrient interactions has been well documented (Adams, 1980; Kirsch, 1959; Murphy et al., 1981; Robson and Pitman, 1983). For example, detrimental effects of $\mathrm{P}$ fertilization on Zn-deficient soils have been reported for many crops (Olsen, 1972). Efforts to uncover the mechanism of the $\mathrm{P}-\mathrm{Zn}$ interaction have led to the study of $\mathrm{P}-\mathrm{Zn}$ reactions in the soil and reactions within the plant involving uptake, translocation, metabolism, and growth. Temperature and $\mathrm{Fe}$ levels have been found to influence P-related Zn disorders (Adams, 1980).

Phosphorus can also interact with B. Boron is essential for root-tip elongation which, in turn, affects $\mathrm{P}$ uptake (Pollard et al., 1977). However, $\mathrm{P}$ also influences B uptake. Bingham and Garber (1960) and Bingham et al. (1958) reported that excessive $\mathrm{P}$ additions reduced uptake of $\mathrm{B}$ in citrus. Boron and phosphates are also involved in complex adsorption and precipitation reactions with sesquioxides and clay minerals in the soil. Thus, the potential for interactions exists at many levels, and the expression of these interactions may depend on environmental conditions or the presence of other nutrients.

Blatt (1976, 1982), working with 'Midway' strawberry on an acidic sandy soil in Nova Scotia, investigated possible P-B interactions under field conditions. Using a factorial approach, he found that neither initial vegetative growth nor subsequent fruit yields were affected by $\mathrm{P}$ or $\mathrm{B}$ additions and that there was no P-B interaction. We also found no P-B interaction at a low $\mathrm{pH}$, 
but we did find a yield response to B that was mediated both through fruit count per inflorescence and fruit size. Although the response of fruit count per inflorescence to B was not statistically significant, this yield component was highly correlated with yield at both $\mathrm{pH}$ levels, and the response surfaces were similar (Figs. 1, 2, 6, and 7).

Boron influences auxin activity (Pilbeam and Kirkby, 1983), and since auxin is related to both inflorescence development and fruit receptacle expansion (Archbold and Dennis, 1985), one would expect yield to respond to supplemental B if its ambient levels were inadequate and $\mathrm{P}$ was adequate. Inflorescence length may be a useful indicator of auxin activity, as this variable was associated with achene spacing on the receptable and was positively associated with yield, fruit size, and applied $\mathrm{B}$ at the lower $\mathrm{pH}$.

Interactions among nutrients may help explain inconsistent responses to applied nutrients that have been reported in the literature. Neilson and Eaton (1983) studied the effects of B nutrition on strawberry yield components using solution culture and found no yield response to B applications from 0.01 to 1.25 ppm. Riggs et al. (1987) found that B applications up to 4.5 $\mathrm{kg} \cdot \mathrm{ha}^{-1}$ decreased yields of 'Tristar' and 'Benton' strawberries on Quatama loam soils suspected to be low in B in the Willamette Valley, Ore. In our study, at a soil $\mathrm{pH}$ of 5.5 , yield responded positively to $\mathrm{B}$. However, at a soil $\mathrm{pH}$ of 6.5 , the responses to applications of $\mathrm{B}$ were either positive, neutral, or negative, depending on the specific level of $\mathrm{P}$ fertilization (Fig. 1).

Our results demonstrated an important shortcoming of field studies that examine single nutrients, without considering interactions with other nutrients. Adams (1980), Kirsch (1959), Murphy et al. (1981), and Sumner and Farina (1986) emphasized the importance of designing nutritional experiments that permit measurements of potential interactions to avoid possible misleading main-effect conclusions.

While it is important for horticulturists to attempt to identify the nutritional conditions that optimize total yield, it is likely that all of the various components contributing to final yield do not have the same nutritional requirements. For example, number of branch crowns, fruit count per inflorescence, fruit weight, and runner production responded differently to additions of $\mathrm{P}$, $\mathrm{Zn}$, and B. Also, responses changed with soil $\mathrm{pH}$. These observations and the finding of interactions suggest that there may not be a single optimum combination of nutrients that maximizes yield. Yield optimization, in reality, likely consists of multiple sets or nutrient levels or ranges, which of themselves are not limiting to plant growth or yield.

There are many inconsistencies in the literature describing the response of strawberries to fertilization (May and Pritts, 1990). Some of these inconsistent responses may reflect nutrient interactions such as those found in our study, while others may reflect variations in climate, soil moisture, soil type, plant condition, and cultural practices. Tissue analysis has been viewed as an invaluable tool to assess the nutritional status of perennial crops and to directly evaluate plant response across a wide range of conditions (Bould, 1964). However, in our study, leaf nutrient levels during the recommended postharvest period in 1988 generally were not related to yield, nor were foliar nutrient concentrations in 1988 correlated with nutrient levels in the soil.

At $\mathrm{pH}$ 6.5, applied $\mathrm{P}$ was correlated with leaf $\mathrm{P}$, which in turn was correlated with fruit P. Applied $\mathrm{Zn}$ was not correlated with foliar $\mathrm{Zn}$, although foliar and fruit $\mathrm{Zn}$ levels were correlated. No correlation existed among soil, foliar, or fruit B or between yield and fruit $\mathrm{P}, \mathrm{B}$, or $\mathrm{Zn}$. Further, B levels in ripening fruit (17 to $22 \mathrm{ppm}$ ) were much lower than foliar levels at the same time (54 to $73 \mathrm{ppm}$ ). Therefore, practices that increase soil nutrient levels may not lead to increased foliar levels, especially if nutrient dilution occurs as growth is stimulated. In addition, a strategy that successfully increases foliar nutrients may not always lead to higher levels in reproductive tissues. Finally, higher levels in reproductive tissues may not be associated with higher yield or fruit quality.

Others have concluded that foliar analyses are not particularly useful indicators of nutrient status for particular elements. Riggs et al. (1987) found that soil applications of B were not effective in increasing total $\mathrm{B}$ in reproductive tissues and that foliar $\mathrm{B}$ levels were a poor predictor of levels in reproductive tissues.

A plant nutrient analysis alone may not be sufficient to identify treatments that will increase yield economically, at least when plants are grown on a reasonably fertile soil. The challenge of understanding nutritional responses is great, considering the thousands of possible interactions that could occur among the 12 mineral nutrients for a single variable under a single set of conditions. Adding to the complexity of evaluating plant nutrient status is the observation that leaf nutrient levels fluctuate seasonally (Fig. 4). Even if one could find specific times when the level of certain nutrients is predictive of plant performance, growers may not accept the time and expense involved with multiple sampling times.

Finally, the results of our study are limited because we examined the response of only a single genotype. Some growers have reported that 'Earliglow' is relatively tolerant to low nutrient levels, but this evidence is anecdotal. With many crop plants, including strawberries (John et al., 1976; Peterson et al., 1986; Renquist and Hughes, 1985), significant genetic variation exists in the ability to extract or absorb nutrients from the rhizosphere or tolerate low levels of nutrients. More work will be required to identify genotypes tolerant to nutrient imbalances.

Nutrient additions significantly affected strawberry yield through various yield components, and these responses were $\mathrm{pH}$ dependent. Interactions among applied nutrients also occurred, making it difficult to predict strawberry plant response under different conditions. Soil type, climate, cultivar, plant condition, cultural practices, and the levels of other plant nutrients also likely influence the response of the strawberry plant to $\mathrm{P}$, $\mathrm{B}$, and $\mathrm{Zn}$. Projections about nutrient responses under differing conditions must be made cautiously, as soil chemistry appears to play a major role in their expression. Our results suggest that no single nutrient optimum exists, and attempts to identify a reasonable balance among plant nutrients cannot be successful using foliar or fruit analysis alone or using the visual appearance of plants. Clearly, the study of nutrient interactions will remain a challenge to horticulturists for many years to come.

\section{Literature Cited}

Adams, F. 1980. Interactions of phosphorus with other elements in soil and plants, p. 655-680. In: F.E. Khasawneh et al. (ed.). The role of phosphorus in agriculture. Amer. Soc. Agron., Madison, Wis.

Archbold, D.D. and F.G. Dennis. 1985. Strawberry receptacle growth and endogenous IAA content as affected by growth regulator application and achene removal. J. Amer. Soc. Hort. Sci. 110:816-820.

Barnette, R.M., J.P. Camp, J.D. Warner, and O.E. Gall. 1936. Use of zinc sulfate under corn and other field crops. Florida Agr. Expt. Sta. Bul. 293:3.

Bingham, F.T. and M.J. Garber, 1960. Solubility and availability of 
micronutrients in relation to phosphorus fertilization. Soil Sci. Soc. Amer. Proc. 24:209-213.

Bingham, F.T., J.P. Martin, and J.A. Chastain. 1958. Effects of phosphorus fertilization of California soils on minor element nutrition of citrus. Soil Sci. 86:24-31.

Blatt, C.R. 1976. Phosphorus and boron interaction on growth of strawberries. HortScience 11:597-599.

Blatt, C.R. 1982. Effects of two boron sources each applied at three rates to the strawberry cv. Midway on soil and leaf boron levels and fruit yields. Commun. Soil Sci. Plant Anal. 13:39-47.

Bould, C. 1964. Leaf analysis as a guide to the nutrition of fruit crops V. Sand culture N, P, K, Mg experiments with strawberry (Fragaria spp.) J. Sci. Food. Agr. 15:474-487.

Box, G.E.P. and N.R. Draper. 1987. Empirical model-building and response surfaces. Wiley, New York. p. 502-525.

Cochran, W.C. and G.M. Cox. 1957. Experimental designs. (2nd ed.), Wiley, New York. p. 346-353.

John, M.K., H.A. Daubeny, F.D. McElroy, and M. Garland. 1976. Genotype influence on elemental composition of strawberry tissues. J. Amer. Soc. Hort. Sci. 101:438-441.

Kirsch, K. 1959. The importance of interaction effects in fertilizer and lime studies with strawberries. Proc. Amer. Soc. Hort. Sci. 73:181188.

May, G. and M. Pritts. 1990. Strawberry nutrition. Adv. Strawberry Prod. 9:10-23.

Mitlehner, A. 1989. Seasonal foliar nutrient levels in strawberries. Proc. Illinois Strawberry School; Mt. Vernon. p. 11-15.

Murphy, L.S., R. Ellis, Jr., and D.C. Adriano. 1981. Phosphorusmicronutrient interaction effects on crop production. J. Plant Nutr. 3:593-613.
Neilson, B.V. and G.W. Eaton. 1983. Effects of boron nutrition upon strawberry yield components. HortScience 18:932-934.

Olsen, S.R. 1972. Micronutrient interactions, p. 243-264. In: J.J. Mortvedt, P.M. Giordano, and W.L. Lindsay (eds.). Micronutrients in agriculture. Soil Sci. Soc. Amer., Madison, Wis.

Ozanne, P.G. 1980. Phosphate nutrition of plants-a general treatise, p. 559-589. In: F.E. Khasawneh et al. (ed.). The role of phosphorus in agriculture. Amer. Soc. Agron., Madison, Wis.

Peterson, L.A., E.J. Stang, and A. Krueger. 1986. Growth and nutrient uptake of strawberry during first-year development in a matted-row cultural system. Adv. Strawberry Prod. 5:11-17.

Pilbeam, D.J. and E.A. Kirkby. 1983. The physiological role of boron in plants. J. Plant Nutr. 6:563-582.

Pollard, A.S., A.J. Parr, and B.C. Loughman. 1977. Boron in relation to membrane function in higher plants. J. Expt. Bot. 28:831-841.

Pritts, M.P., W.F. Wilcox, A. Agnello, and G.A. Schaefers. 1988. Cornell recommendations for small-fruits production. Cornell Coop. Ext. Publ., Research Park, Ithaca, N.Y.

Renquist, A.R. and H.G. Hughes. 1985. Strawberry cultivar evaluation in Colorado: 1982-1984. Adv. Strawberry Prod. 4:53-55.

Riggs, D.J.M., T.L. Righetti, and L.W. Martin. 1987. The effect of boron application on boron partitioning in Tristar and Benton strawberries. Commun. Soil Sci. Plant Anal. 18:1453-1467,

Robson, A.D. and M.G. Pitman. 1983. Interactions between nutrients in higher plants, p. 147-180. In: A. Läuchli and R.L. Bieleski (eds.). Inorganic plant nutrition. vol. 15 (A), Springer Verlag.

Sumner, M.E. and M.P.W. Farina. 1986. Phosphorus interactions with other nutrients and lime in field cropping systems Adv. Soil Sci. 5:201-236.

West, E.S. 1938. Zinc-cured mottle leaf in citrus induced by excess phosphate. Austral. Council Sci. Ind. Res. J. 11:182-184. 
sponse surface. Fifteen treatment combinations from five levels each of $\mathrm{P}, \mathrm{Zn}$, and B (Table 1) were selected according to design criteria. Treatments were applied in a randomized completeblock design and replicated three times, at two $\mathrm{pH}$ levels (5.5 and 6.5), for a total of 90 experimental units with dimensions of $2.5 \times 3.5 \mathrm{~m}$ each.

Nutrients were soil-incorporated before planting. Rates of application ranged from 11 to $123 \mathrm{~kg} \mathrm{P} / \mathrm{ha}$ as triple super phosphate, 2.8 to $45 \mathrm{~kg} \mathrm{Zn} / \mathrm{ha}$ as zinc sulfate, and 0.2 to $4.5 \mathrm{~kg} \mathrm{~B} /$ ha as sodium octaborate. Ground agricultural limestone was used to adjust soil $\mathrm{pH}$ level in half of the plots from the existing $\mathrm{pH}$ of 5.5 to 6.5 .

Applications of P, Zn, B, and lime were made in Oct. 1986 before rototilling of each plot. To ensure uniform distribution, zinc sulfate and sodium octaborate were first dissolved in water, then applied to each plot using a hand sprayer. Other than $\mathrm{N}$, no additional nutrients were applied during the course of the experiment. Subsequent soil testing (ammonium acetate extraction) was conducted in Spring and Fall 1987 and in Spring 1988.

On 23 Apr. 1987, certified nursery plants of 'Earliglow' were planted $30 \mathrm{~cm}$ on square, forming a 40-plant grid in each plot. Standard cultural practices were followed (Pritts et al., 1988), with the exception that runners were removed so plants did not form a solid bed. Napropamide at $2.2 \mathrm{~kg} \cdot \mathrm{ha}^{-1}$ was applied 2 weeks after planting and again at $4.5 \mathrm{~kg} \cdot \mathrm{ha}^{-1}$ before straw mulch application in November. Ammonium nitrate was applied 6 weeks after planting to supply $34 \mathrm{~kg} \mathrm{~N} / \mathrm{ha}$, and calcium nitrate was applied in early September to supply $22 \mathrm{~kg} \mathrm{~N} / \mathrm{ha}$. Soil moisture was maintained near field capacity throughout the study with overhead irrigation, as indicated by soil moisture tensiometers.

Runners were removed weekly to maintain a constant plant density within each plot. Entire plants were excavated beginning 2 June 1987 and continuing at $\approx 30$-day intervals throughout the first year of establishment (1987) and first fruiting season (1988). Plants were separated into roots, crowns, petioles, leaf blades, and fruit, washed with tap water, then rinsed with distilled water. Plant material was oven-dried at $65 \mathrm{C}$, weighed, and ground in a Wiley mill to pass through square grids $1.4 \times 1.7 \mathrm{~mm}$.

Nitrogen concentration in leaf lamina was determined by a Kjeldahl procedure. The $\mathrm{P}, \mathrm{K}, \mathrm{Ca}, \mathrm{Mg}, \mathrm{Fe}, \mathrm{Zn}, \mathrm{B}, \mathrm{Mn}, \mathrm{Cu}$,

Table 1. Treatment combinations specified by the three-factor, rotatable, central composite design and corresponding yields in 1988 at $\mathrm{pH} 5.5$ and 6.5 .

\begin{tabular}{|c|c|c|c|c|c|}
\hline \multirow{2}{*}{$\begin{array}{c}\text { Treatment } \\
\text { number }\end{array}$} & \multirow{2}{*}{$\frac{\mathrm{P}}{\mathrm{kg} \cdot \mathrm{ha} \mathrm{a}^{-1}}$} & \multirow{2}{*}{$\frac{\mathrm{Zn}}{\mathrm{kg} \cdot \mathrm{ha}^{-1}}$} & \multirow{2}{*}{$\frac{\mathrm{B}}{\mathrm{kg} \cdot \mathrm{ha} \mathrm{a}^{-1}}$} & \multicolumn{2}{|c|}{ Yield (g) } \\
\hline & & & & $\mathrm{pH}=5.5$ & $\mathrm{pH}=6.5$ \\
\hline 1 & 11.2 & 23.9 & 2.4 & $1544^{z}$ & 1507 \\
\hline 2 & 33.6 & 11.4 & 1.1 & 1369 & 1544 \\
\hline 3 & 33.6 & 11.4 & 3.6 & 1460 & 1688 \\
\hline 4 & 33.6 & 36.3 & 1.1 & 1450 & 1172 \\
\hline 5 & 33.6 & 36.3 & 3.6 & 2019 & 1513 \\
\hline 6 & 67.3 & 2.9 & 2.4 & 1293 & 1629 \\
\hline 7 & 67.3 & 23.9 & 0.2 & 1474 & 1386 \\
\hline 8 & 67.3 & 23.9 & 2.4 & 1233 & 1372 \\
\hline 9 & 67.3 & 23.9 & 4.5 & 1428 & 1566 \\
\hline 10 & 67.3 & 44.8 & 2.4 & 1506 & 1099 \\
\hline 11 & 100.9 & 11.4 & 1.1 & 1456 & 1453 \\
\hline 12 & 100.9 & 11.4 & 3.6 & 1655 & 1957 \\
\hline 13 & 100.9 & 36.3 & 1.1 & 1494 & 1243 \\
\hline 14 & 100.9 & 36.3 & 3.6 & 1645 & 1482 \\
\hline 15 & 123.3 & 23.9 & 2.4 & 1766 & 1440 \\
\hline SE & & & & 43 & 43 \\
\hline
\end{tabular}

${ }^{2}$ Means are the average of three six-plant replicates. and Mo content was determined by inductively coupled plasma spectroscopy (Model 975 Plasma Atomcomp ICP Spectrograph with ICAP 61 Update, Jarrell-Ash, Pittsburgh). Leaf area was determined using a portable area meter (LI-COR Model LI3100, Lincoln, Neb. Aboveground plant dry weight, number of branch crowns and fruit per inflorescence, inflorescence length, fruit count per plant, fruit weight, achenes per square centimeter of surface, and fruit weight per achene were recorded at each sampling date. Yield component data were pooled for each plot. A final leaf sample for tissue nutrient analysis was collected $\approx 5$ weeks after postharvest leaf removal. Fruit soluble solids concentration (SSC) was determined with a hand-held refractometer (Thomas Scientific, Swedesboro, N.J.).

Statistical analysis of the central composite design was used to derive meaningful regression equations that accurately described the response surfaces for the variables of interest. Values for nutrient concentrations were transformed before analysis by first subtracting the mean, then dividing by it, resulting in a scale from -1 to 1 for each nutrient. Using a transformed scale in regression analysis has three advantages over using the actual levels of applied nutrient. First, regardless of the nutrient involved, -1 represents a low level and +1 a high level. This scheme is important when the differences in ranges between low and high levels are very large (as was the case with $\mathrm{P}$ and B). Second, the transformed variables are orthogonal, allowing unbiased estimates of regression coefficients to be calculated. Third, regression coefficients among components of the model can be compared directly with each other. Also, this standardized scale can be converted easily to the actual applied values through multiplication.

These new, orthogonal variables were used in regression analysis to calculate the response surface, using the following full model: Response $=$ Block $+\mathrm{P}+\mathrm{Zn}+\mathrm{B}+\mathrm{P} \times \mathrm{Zn}$ $+\mathrm{P} \times \mathrm{B}+\mathrm{B} \times \mathrm{Zn}+\mathrm{P}^{2}+\mathrm{B}^{2}+\mathrm{Zn}^{2}$.

Sequential sums of squares were accumulated for the full model. Single-degree-of-freedom F tests were then used to evaluate the significance of the individual components of the model. For the generation of response surfaces, new models were constructed using only the significant terms from the full model, with the exception of fruit count per inflorescence, where the full model was used (since the full model was significant, but individual coefficients were not).

\section{Results}

Preplant, soil-applied nutrient additions of $\mathrm{P}, \mathrm{Zn}$, and B were correlated with soil test results in each of the 2 years (Table 2). A decrease of $\approx 0.5 \mathrm{pH}$ units was measured during the course of the experiment in plots that initially received lime applications. Plant growth variables were unaffected by liming; however, yield components were affected differently at $\mathrm{pH} 5.5$ and 6.5 , so results are discussed separately.

Results at $p H$ 6.5. Yield increased with increasing B at a high $\mathrm{P}$ level but decreased at a low $\mathrm{P}$ level (Table 1, Fig. 1 top).

Table 2. Significant $(P<0.01)$ correlation coefficients $(r)$ between mineral nutrient treatment levels (1986) and soil test values (1987 and 1988).

\begin{tabular}{lccc}
\hline \hline Soil test & P & Zn & B \\
\hline Spring 1987 & 0.94 & 0.97 & 0.84 \\
Fall 1987 & 0.74 & 0.65 & NS \\
Spring 1988 & 0.55 & 0.93 & 0.71 \\
\hline
\end{tabular}

NSNonsignificant. 


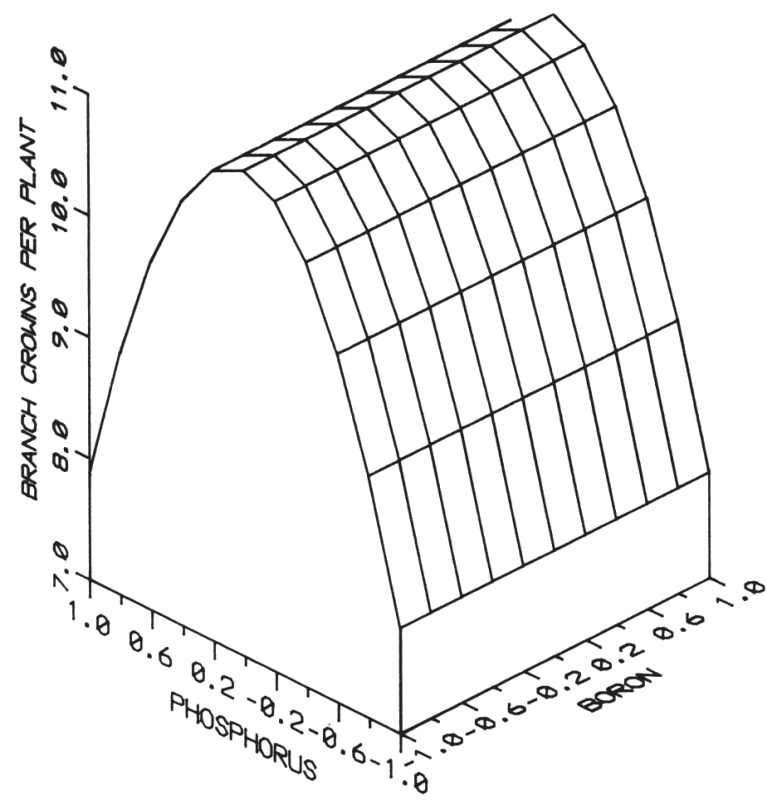

Fig. 3. Response of branch crowns per plant to $\mathrm{P}$ and $\mathrm{B}$ at $\mathrm{Zn}=0$ $\left(23.9 \mathrm{~kg} \cdot \mathrm{ha}^{-1}\right)$ and $\mathrm{pH}=6.5$. Branch crown count $=11.0-$ $3.13\left(\mathrm{P}^{2}\right), R^{2}=0.09, P<0.05$. For scale conversion, units of $\mathrm{P}$ range from $11.2(-1)$ to $123.3(1) \mathrm{kg} \cdot \mathrm{ha}^{-1}$ and $\mathrm{B}$ from $0.2(-1)$ to $4.5(1) \mathrm{kg} \cdot \mathrm{ha}^{-1}$.

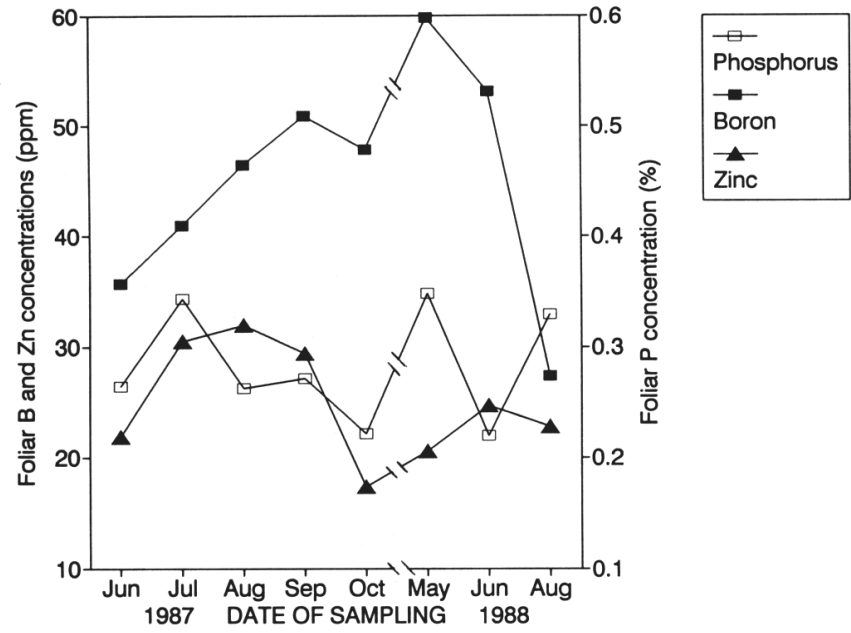

Fig. 4. Seasonal pattern of $\mathrm{P}, \mathrm{B}$, and $\mathrm{Zn}$ concentration in leaf lamina of plants set in Apr. 1987 and harvested over the following 16 months for the central treatment of the design of the experiment $\left(\mathrm{kg} \cdot \mathrm{ha}^{-1}\right.$ : $67 \mathrm{P}, 23.9 \mathrm{Zn}$, and $\left.2.35 \mathrm{~B}\right)$.

with yield. For $\mathrm{K}, \mathrm{P}, \mathrm{Ca}, \mathrm{Mn}, \mathrm{Cu}$, and $\mathrm{Zn}$, foliar and fruit levels were correlated positively, but no correlation existed for levels of $\mathrm{Mg}, \mathrm{Fe}$, or B. Plant size was not correlated with yield.

Results at $p H$ 5.5. Strawberry yields were significantly affected by B (Fig. 6), but the interaction of $\mathrm{B}$ with $\mathrm{P}$ or $\mathrm{Zn}$ was not significant (Table 3). Boron applications increased yield regardless of $\mathrm{P}$ and $\mathrm{Zn}$ levels. As at the higher $\mathrm{pH}$, fruit count per inflorescence $(r=0.65, P<0.001)$ and individual fruit weight $(r=0.31, P<0.04)$ were correlated with yield, and their responses to nutrient additions somewhat paralleled the yield response (Figs. 7 and 8). Again, although the response of fruit count per inflorescence was very similar to that of yield, regression coefficients that describe the response of this variable to nutrient additions were not significant (Fig. 8).

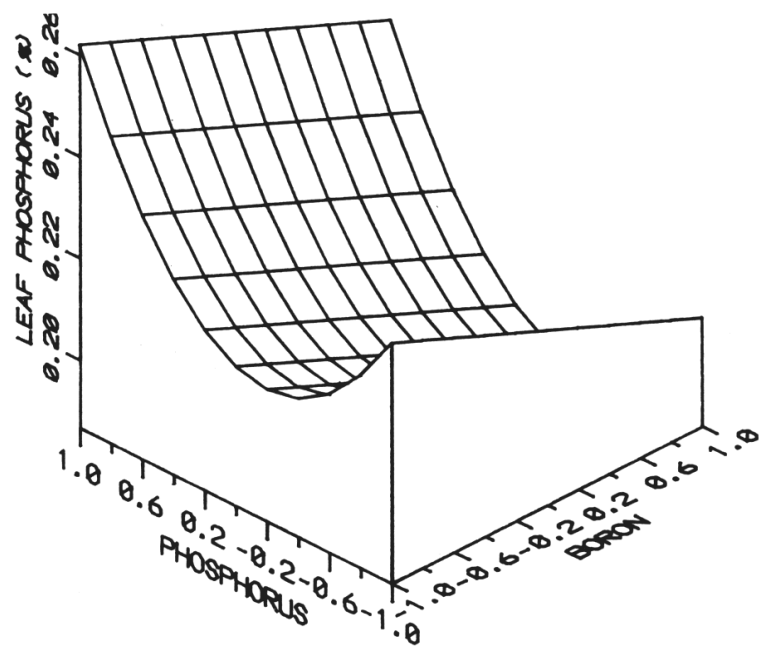

Fig. 5. Response of leaf $\mathrm{P}$ at renovation to $\mathrm{P}$ and $\mathrm{B}$ at $\mathrm{Zn}=0(23.9$ $\mathrm{kg} \cdot \mathrm{ha}^{-1}$ ) and $\mathrm{pH}=6.5$. Percent leaf $\mathrm{P}=0.201+0.014(\mathrm{P})+$ $0.034\left(\mathrm{P}^{2}\right)-0.013(\mathrm{~B})-0.03\left(\mathrm{~B}^{*} \mathrm{Zn}\right), R^{2}=0.339, P<0.002$. For scale conversion, units of $\mathrm{P}$ range from $11.2(-1)$ to $123.3(1)$ $\mathrm{kg} \cdot \mathrm{ha}^{-1}$ and B from $0.2(-1)$ to $4.5(1) \mathrm{kg} \cdot \mathrm{ha}^{-1}$.

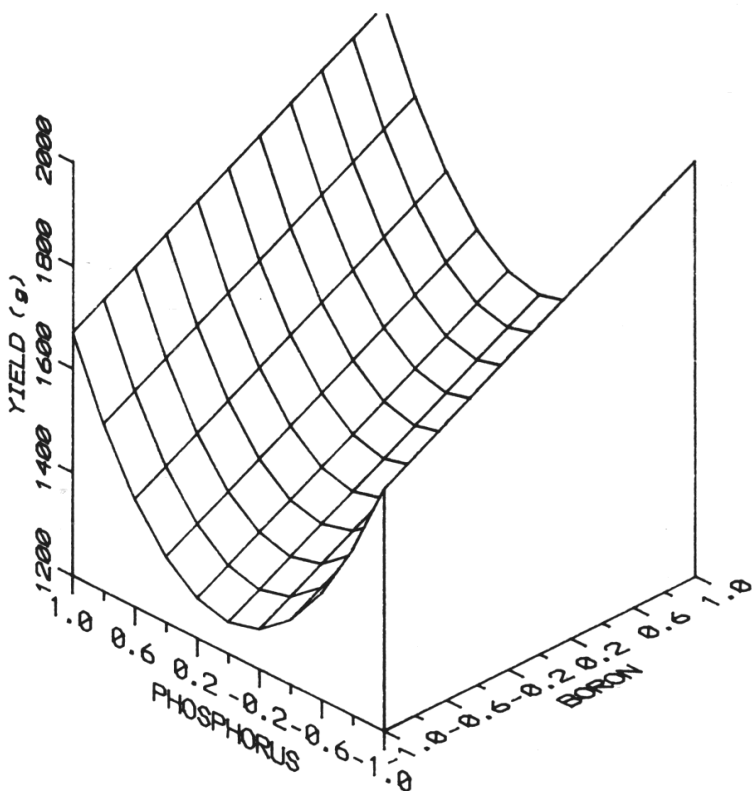

Fig. 6. Yield response (grams per six plants) to $\mathrm{P}$ and $\mathrm{B}$ at $\mathrm{Zn}=0$ $\left(23.9 \mathrm{~kg} \cdot \mathrm{ha}^{-1}\right)$ and $\mathrm{pH}=5.5$. Yield $=1427+410\left(\mathrm{P}^{2}\right)+166(\mathrm{~B})$, $R^{2}=0.153, P<0.03$. For scale conversion, units of $\mathrm{P}$ range from $11.2(-1)$ to $123.3(1) \mathrm{kg} \cdot \mathrm{ha}^{-1}$ and B from $0.2(-1)$ to $4.5(1)$ $\mathrm{kg} \cdot \mathrm{ha}^{-1}$.

Nutrient additions had no effect on inflorescence count, fruit SSC, or achene spacing (Table 3). Inflorescence length, however, was positively correlated with fruit size $(r=0.39, P<$ $0.009)$, yield $(r=0.36, P<0.02)$, achene spacing $(r=0.34$, $P<0.02)$, and the level of applied B $(r=0.31, P<0.04)$.

Leaf $\mathrm{P}$ at renovation showed a quadratic response to soilapplied $\mathrm{P}$ (data not shown), similar to that at the higher $\mathrm{pH}$ (Fig. 5). Leaf $\mathrm{B}$ exhibited a quadratic response to $\mathrm{P}(P<0.06)$ but not to B additions (data not shown).

Leaf $\mathrm{Zn}$ at renovation was negatively correlated with yield $(P<0.06)$, but correlations of yield with other foliar nutrient levels at renovation were not significant (data not shown). Fruit and leaf nutrient levels were correlated positively for $\mathrm{P}, \mathrm{Mn}$, 
but we did find a yield response to B that was mediated both through fruit count per inflorescence and fruit size. Although the response of fruit count per inflorescence to B was not statistically significant, this yield component was highly correlated with yield at both $\mathrm{pH}$ levels, and the response surfaces were similar (Figs. 1, 2, 6, and 7).

Boron influences auxin activity (Pilbeam and Kirkby, 1983), and since auxin is related to both inflorescence development and fruit receptacle expansion (Archbold and Dennis, 1985), one would expect yield to respond to supplemental B if its ambient levels were inadequate and $\mathrm{P}$ was adequate. Inflorescence length may be a useful indicator of auxin activity, as this variable was associated with achene spacing on the receptable and was positively associated with yield, fruit size, and applied $\mathrm{B}$ at the lower $\mathrm{pH}$.

Interactions among nutrients may help explain inconsistent responses to applied nutrients that have been reported in the literature. Neilson and Eaton (1983) studied the effects of B nutrition on strawberry yield components using solution culture and found no yield response to B applications from 0.01 to 1.25 ppm. Riggs et al. (1987) found that B applications up to 4.5 $\mathrm{kg} \cdot \mathrm{ha}^{-1}$ decreased yields of 'Tristar' and 'Benton' strawberries on Quatama loam soils suspected to be low in B in the Willamette Valley, Ore. In our study, at a soil $\mathrm{pH}$ of 5.5 , yield responded positively to $\mathrm{B}$. However, at a soil $\mathrm{pH}$ of 6.5 , the responses to applications of $\mathrm{B}$ were either positive, neutral, or negative, depending on the specific level of $\mathrm{P}$ fertilization (Fig. 1).

Our results demonstrated an important shortcoming of field studies that examine single nutrients, without considering interactions with other nutrients. Adams (1980), Kirsch (1959), Murphy et al. (1981), and Sumner and Farina (1986) emphasized the importance of designing nutritional experiments that permit measurements of potential interactions to avoid possible misleading main-effect conclusions.

While it is important for horticulturists to attempt to identify the nutritional conditions that optimize total yield, it is likely that all of the various components contributing to final yield do not have the same nutritional requirements. For example, number of branch crowns, fruit count per inflorescence, fruit weight, and runner production responded differently to additions of $\mathrm{P}$, $\mathrm{Zn}$, and B. Also, responses changed with soil $\mathrm{pH}$. These observations and the finding of interactions suggest that there may not be a single optimum combination of nutrients that maximizes yield. Yield optimization, in reality, likely consists of multiple sets or nutrient levels or ranges, which of themselves are not limiting to plant growth or yield.

There are many inconsistencies in the literature describing the response of strawberries to fertilization (May and Pritts, 1990). Some of these inconsistent responses may reflect nutrient interactions such as those found in our study, while others may reflect variations in climate, soil moisture, soil type, plant condition, and cultural practices. Tissue analysis has been viewed as an invaluable tool to assess the nutritional status of perennial crops and to directly evaluate plant response across a wide range of conditions (Bould, 1964). However, in our study, leaf nutrient levels during the recommended postharvest period in 1988 generally were not related to yield, nor were foliar nutrient concentrations in 1988 correlated with nutrient levels in the soil.

At $\mathrm{pH}$ 6.5, applied $\mathrm{P}$ was correlated with leaf $\mathrm{P}$, which in turn was correlated with fruit P. Applied $\mathrm{Zn}$ was not correlated with foliar $\mathrm{Zn}$, although foliar and fruit $\mathrm{Zn}$ levels were correlated. No correlation existed among soil, foliar, or fruit B or between yield and fruit $\mathrm{P}, \mathrm{B}$, or $\mathrm{Zn}$. Further, B levels in ripening fruit (17 to $22 \mathrm{ppm}$ ) were much lower than foliar levels at the same time (54 to $73 \mathrm{ppm}$ ). Therefore, practices that increase soil nutrient levels may not lead to increased foliar levels, especially if nutrient dilution occurs as growth is stimulated. In addition, a strategy that successfully increases foliar nutrients may not always lead to higher levels in reproductive tissues. Finally, higher levels in reproductive tissues may not be associated with higher yield or fruit quality.

Others have concluded that foliar analyses are not particularly useful indicators of nutrient status for particular elements. Riggs et al. (1987) found that soil applications of B were not effective in increasing total $\mathrm{B}$ in reproductive tissues and that foliar $\mathrm{B}$ levels were a poor predictor of levels in reproductive tissues.

A plant nutrient analysis alone may not be sufficient to identify treatments that will increase yield economically, at least when plants are grown on a reasonably fertile soil. The challenge of understanding nutritional responses is great, considering the thousands of possible interactions that could occur among the 12 mineral nutrients for a single variable under a single set of conditions. Adding to the complexity of evaluating plant nutrient status is the observation that leaf nutrient levels fluctuate seasonally (Fig. 4). Even if one could find specific times when the level of certain nutrients is predictive of plant performance, growers may not accept the time and expense involved with multiple sampling times.

Finally, the results of our study are limited because we examined the response of only a single genotype. Some growers have reported that 'Earliglow' is relatively tolerant to low nutrient levels, but this evidence is anecdotal. With many crop plants, including strawberries (John et al., 1976; Peterson et al., 1986; Renquist and Hughes, 1985), significant genetic variation exists in the ability to extract or absorb nutrients from the rhizosphere or tolerate low levels of nutrients. More work will be required to identify genotypes tolerant to nutrient imbalances.

Nutrient additions significantly affected strawberry yield through various yield components, and these responses were $\mathrm{pH}$ dependent. Interactions among applied nutrients also occurred, making it difficult to predict strawberry plant response under different conditions. Soil type, climate, cultivar, plant condition, cultural practices, and the levels of other plant nutrients also likely influence the response of the strawberry plant to $\mathrm{P}$, $\mathrm{B}$, and $\mathrm{Zn}$. Projections about nutrient responses under differing conditions must be made cautiously, as soil chemistry appears to play a major role in their expression. Our results suggest that no single nutrient optimum exists, and attempts to identify a reasonable balance among plant nutrients cannot be successful using foliar or fruit analysis alone or using the visual appearance of plants. Clearly, the study of nutrient interactions will remain a challenge to horticulturists for many years to come.

\section{Literature Cited}

Adams, F. 1980. Interactions of phosphorus with other elements in soil and plants, p. 655-680. In: F.E. Khasawneh et al. (ed.). The role of phosphorus in agriculture. Amer. Soc. Agron., Madison, Wis.

Archbold, D.D. and F.G. Dennis. 1985. Strawberry receptacle growth and endogenous IAA content as affected by growth regulator application and achene removal. J. Amer. Soc. Hort. Sci. 110:816-820.

Barnette, R.M., J.P. Camp, J.D. Warner, and O.E. Gall. 1936. Use of zinc sulfate under corn and other field crops. Florida Agr. Expt. Sta. Bul. 293:3.

Bingham, F.T. and M.J. Garber, 1960. Solubility and availability of 
micronutrients in relation to phosphorus fertilization. Soil Sci. Soc. Amer. Proc. 24:209-213.

Bingham, F.T., J.P. Martin, and J.A. Chastain. 1958. Effects of phosphorus fertilization of California soils on minor element nutrition of citrus. Soil Sci. 86:24-31.

Blatt, C.R. 1976. Phosphorus and boron interaction on growth of strawberries. HortScience 11:597-599.

Blatt, C.R. 1982. Effects of two boron sources each applied at three rates to the strawberry cv. Midway on soil and leaf boron levels and fruit yields. Commun. Soil Sci. Plant Anal. 13:39-47.

Bould, C. 1964. Leaf analysis as a guide to the nutrition of fruit crops V. Sand culture N, P, K, Mg experiments with strawberry (Fragaria spp.) J. Sci. Food. Agr. 15:474-487.

Box, G.E.P. and N.R. Draper. 1987. Empirical model-building and response surfaces. Wiley, New York. p. 502-525.

Cochran, W.C. and G.M. Cox. 1957. Experimental designs. (2nd ed.), Wiley, New York. p. 346-353.

John, M.K., H.A. Daubeny, F.D. McElroy, and M. Garland. 1976. Genotype influence on elemental composition of strawberry tissues. J. Amer. Soc. Hort. Sci. 101:438-441.

Kirsch, K. 1959. The importance of interaction effects in fertilizer and lime studies with strawberries. Proc. Amer. Soc. Hort. Sci. 73:181188.

May, G. and M. Pritts. 1990. Strawberry nutrition. Adv. Strawberry Prod. 9:10-23.

Mitlehner, A. 1989. Seasonal foliar nutrient levels in strawberries. Proc. Illinois Strawberry School; Mt. Vernon. p. 11-15.

Murphy, L.S., R. Ellis, Jr., and D.C. Adriano. 1981. Phosphorusmicronutrient interaction effects on crop production. J. Plant Nutr. 3:593-613.
Neilson, B.V. and G.W. Eaton. 1983. Effects of boron nutrition upon strawberry yield components. HortScience 18:932-934.

Olsen, S.R. 1972. Micronutrient interactions, p. 243-264. In: J.J. Mortvedt, P.M. Giordano, and W.L. Lindsay (eds.). Micronutrients in agriculture. Soil Sci. Soc. Amer., Madison, Wis.

Ozanne, P.G. 1980. Phosphate nutrition of plants-a general treatise, p. 559-589. In: F.E. Khasawneh et al. (ed.). The role of phosphorus in agriculture. Amer. Soc. Agron., Madison, Wis.

Peterson, L.A., E.J. Stang, and A. Krueger. 1986. Growth and nutrient uptake of strawberry during first-year development in a matted-row cultural system. Adv. Strawberry Prod. 5:11-17.

Pilbeam, D.J. and E.A. Kirkby. 1983. The physiological role of boron in plants. J. Plant Nutr. 6:563-582.

Pollard, A.S., A.J. Parr, and B.C. Loughman. 1977. Boron in relation to membrane function in higher plants. J. Expt. Bot. 28:831-841.

Pritts, M.P., W.F. Wilcox, A. Agnello, and G.A. Schaefers. 1988. Cornell recommendations for small-fruits production. Cornell Coop. Ext. Publ., Research Park, Ithaca, N.Y.

Renquist, A.R. and H.G. Hughes. 1985. Strawberry cultivar evaluation in Colorado: 1982-1984. Adv. Strawberry Prod. 4:53-55.

Riggs, D.J.M., T.L. Righetti, and L.W. Martin. 1987. The effect of boron application on boron partitioning in Tristar and Benton strawberries. Commun. Soil Sci. Plant Anal. 18:1453-1467,

Robson, A.D. and M.G. Pitman. 1983. Interactions between nutrients in higher plants, p. 147-180. In: A. Läuchli and R.L. Bieleski (eds.). Inorganic plant nutrition. vol. 15 (A), Springer Verlag.

Sumner, M.E. and M.P.W. Farina. 1986. Phosphorus interactions with other nutrients and lime in field cropping systems Adv. Soil Sci. 5:201-236.

West, E.S. 1938. Zinc-cured mottle leaf in citrus induced by excess phosphate. Austral. Council Sci. Ind. Res. J. 11:182-184. 